\title{
Acaricidal Activity of Some Lamiaceae Plant Essential Oils against Tetranychus urticae Koch
}

\author{
Sanaa, A. A. Amer ; Fatma, S. A. Mohamed ${ }^{* *}$; A. M. Kamel ${ }^{* * *}$; \\ Zakeya, E. A. Darwish $^{* *}$; Huda, E. Hussein ${ }^{*}$ and Marwa, E. El-Desouky ${ }^{*}$ \\ *Plant Protection Dept., National Research Center (N R C), Dokki, Giza, Egypt \\ ${ }^{* *}$ Invertebrates, Zoology Dept., Faculty of Sci., AL-A Zhar Univ., for Girls, Cairo, Egypt \\ ${ }^{* * *}$ Medicinal and Aromatic Plants Dept., N R C, Dokki, Giza, Egypt
}

\begin{abstract}
Three plant essential oils, namely, Mentha longifolia L., Salvia officinalis L. and Dracocephalum moldavicae L. were snalyzed by GC/MS and tested for their toxicity and repellency against the tetranychid mite Tetranychus urticae Koch. 5. moldavicae proved to be the most effective against $T$. urticae followed by $S$. officinalis and $M$. longifolia. The $\mathrm{LC}_{50}$ values were $1.57 \& 0.58 ; 2.24 \& 3.33$ and $2.85 \& 3.52$ for adults and eggs, respectively. However, all essential oils tested showed high repellency, shortened female longevity and oviposition period as well as reduction in the total number of deposited eggs. This result may be correlated to the differences in the chemical structure of these oils based on GC/MS analysis.
\end{abstract}

Key Words: Acaricidal, Lamiaceae, Tetranychus urticae, Mentha longifolia, Salvia officinalis, Dracocephalum moldavicae, Essential oils.

\section{INTRODUCTION}

The two- spotted spider mite, Tetranychus urticae Koch is considered to be one of the most economically important pests. It is responsible for significant yield losses in many horticultural, ornamental and agricultural systems mainly annual srops and vegetables worldwide, and affects plants by direct feeding, thereby reducing the area of photosynthesis activity causing leaf abscission (Helle\& Sabelis, 1985).

In recent years, the use of synthetic organic pesticides in crop pest control programs around the world has resulted in damage to the environment, pest resurgence, pest resistance to pesticides and lethal effects on non-target organisms (Gorman et al., 2002; Cohen, 2006; Hardman el al., 2006; Kim et al., 2007 and van Leeuwen, et al., 2010).

So, increasing concern about potential problems associated with continued long-term use of toxic pesticides requires development of biodegradable and environmentally safe alternatives.

Among alternative strategies, the use oi aromatic plants and their essential oils represented a rich source of bioactive chemicals (Regnault-Roger, 1997).

Aromatic plants have minimal toxicity on mammals, minimal development of resistance and act as oviposition-deterrent, antifeedant and growth inhibitors (Ibrahim et al., 2001 and Bakkali, et al., 2008)
More than 2.000 species of plants are known to possess acaricidal properties (Klocke, 1989) and family Lamiaceae is one of them. This family has received the most attention in the search for biologically active natural products against many pests (e. g.: Mansour et al., 1986; Tunc \& Sahinkaya, 1998 and Calmasur et al., 2006). So, much attention has been focused on these plants and their constituents as potential sources of commercial acaricides.

The objectives of the present work were:-

1- To identify the chemical constituents of wild mint:, Mentha longifolia L., sage; Salvia officinalis L. and dragon head, Dracocephalum moldavicae L. oils.

2- To determine the efficiency of these oils and their acaricidal activities against $T$. urticue

3- Deterrent effects of these oils and effects on some biological aspects of T.urticae were also studied.

\section{MATERIALS AND METHODS}

\section{Mite rearing:}

T. urticae was collected from infested kidney bean, Phaseolus vulgaries L., and reared in the laboratory at $\mathrm{N} \mathrm{R} \mathrm{C}$, under controlled conditions of $26 \pm 2^{\circ} \mathrm{C}$ and $70 \pm 5 \%$ R.H.

\section{Plant materials:}

Plants that proven to contain essential oils were chosen from family Lamiaceae and were identifice by Prof. Dr. Loutfy Boulos. Department of Piant Taxonomy, National Research Center $M$ longifolia was obtained from Mehalit Zaiad village -.. 
Gharbia while $S$. officinalis was obtained from the Faculty of Agriculture, Cairo University farm, and D. moldavicae from N R C, experimental farm. All plants were collected at flowering stage.

\section{Separation of essential oils:}

A dried aerial part of each plant was crushed, then essential oils were extracted by hydrodistillation apparatus (Clevenger-type) for 3-hrs. The obtained oil from each plant was dried over anhydrous sodium sulfate, and after filtration, kept in the freezer until used.

Different concentrations of the oils were prepared using two drops of Triton $\mathrm{X}-100$ to serve as emulsifier.

\section{GC/ MS analysis of essential oil:}

The analysis of essential oil was performed using THERMO trace 2000 gas chromatography linked to FINNIGAN SSQ7000 mass spectrometer. Ionization mode: Eleven 70. Column: capillary column of fused silica, DB-5 (5\% phenyl methyl siloxane), $30 \mathrm{~m}$ length and $0.25 \mu \mathrm{m}$ thickness. The carrier gas was helium at $1 \mathrm{ml} / \mathrm{min}$. The volume of the injected sample was $1 \mu \mathrm{l}$ in split less mode. Initial temp. $60^{\circ} \mathrm{C}$ for $15 \mathrm{~min}$, and increasing from $60^{\circ} \mathrm{C}$ to $220^{\circ} \mathrm{C}$, with a rate of $5^{\circ} \mathrm{C} / \mathrm{min}$., the final temp. was $250^{\circ} \mathrm{C}$ for $15 \mathrm{~min}$., ionization voltage was $70 \mathrm{eV}$. The major components of essential oils were identified on the basis of comparison of their retention indexes and mass spectra with those of published data (Adams, 2001).

\section{Treatments:}

Toxicity effects of Mentha longifolia, Salvia officinalis and Dracocephalum moldavicae on T. urticae eggs and adult females:

Eggs (0-24 hr age) or adult females of the same age were transferred to the lower surface of raspberry leaf discs $(3 \mathrm{~cm}$. diameter) and sprayed with different concentrations from each essential oil using glass atomizer. Each test contained 5 concentrations and each concentration had 5 replicates (20 females/replicate and 40 eggs/ replicate). In each test, a control was included using distilled water and two drops of Triton X-100. The mortality of the females was recorded after $48 \mathrm{hr}$ and after 6 days for eggs.

\section{Repellency test procedure for $T$. urticae females:}

Raspberry leaf dises ( $5 \mathrm{~cm}$ diam.) were prepared with lower surfaces upside-down in Petri- dish, lined with moist cotton wool. One half of each disc was painted with series of aqueous concentrations beginning with $\mathrm{LC}_{50}$ values of each essential oil and each $\mathrm{LC}_{50}$ value was diluted to each half and so on, till the fourth concentration, while the other half left untreated served as control. Ten females were put on the mid-rib of the leaf. Orientation of the females on treated or control half was recorded after 2, 4, 6, 24 and 48-hr. The number of eggs laid on each half were recorded after $48 \mathrm{hr}$. Tests were replicated 10 times for each concentration.

\section{Effect of $\mathrm{LC}_{50}$ of essential oils on some biological aspects of $T$. urticae females:}

Newly emerged mated females were sprayed with $\mathrm{LC}_{50}$ of each essential oil using glass atomizer, then twenty females of the surviving individuals were singly transferred to treated raspberry leaf discs with $\mathrm{LC}_{50}$ of each essential oil in Petri-dishes. Twenty replicates were used in the experiment and a control was included also. The biological parameters tested were pre-oviposition and oviposition periods, female longevity, total number of eggs deposited by females and also egg hatchability.

All experiments were carried out in the laboratory at $26 \pm 2{ }^{\circ} \mathrm{C}$ and $70 \pm 5 \%$ R.H.

\section{Statistical analysis:}

Corrected mortality was counted according to Abbott's formula. Corrected mortality (\%) was submitted to probit analysis according to the formula described by Finney (1971).

The repellency was calculated according to Lwande et al., (1985):

\section{Where:}

$$
\mathrm{D}=(1-\mathrm{T} / \mathrm{C}) \times 100
$$

$\mathrm{T}=$ mean number of eggs/female in treatment.
$\mathrm{C}=$ mean number of eggs/female in control.

Biological data were statistically analyzed using the SPSS program, version 11; a significance of results was obtained by one-way ANOVA. Duncan's Multiple Range Test was used to compare means according to Duncan.

\section{RESULTS AND DISCUSSION}

\section{GC/ MS analysis of essential oils}

Table \& Fig. (1) show the quantitative analysis of M. longifolia oil. The obtained data showed that oil was mainly characterized by high concentration of total terpene compounds $(84.19 \%)$ and low concentration of hydrocarbons $(2.55 \%)$. Cis-Piperitone oxide and trans-piperitone oxide were the major compounds $(34.42 \%$ and $19.31 \%)$, respectively. Similarly, S. officinalis oil (Table \& Fig. 2) and D. moldavicae oil (Table \& Fig. 3), were characterized by higher concentration of total terpenes ( $88.35 \& 93.32 \%$ ), respectively. The major compound of $S$. officinalis oil was found to be 1 , 8- cineole (18.64\%) and to be geranyl acetate $(29.99 \%)$ in D. moldavicae oil. 
RT: $0.00-47.02$ SM: $7 G$

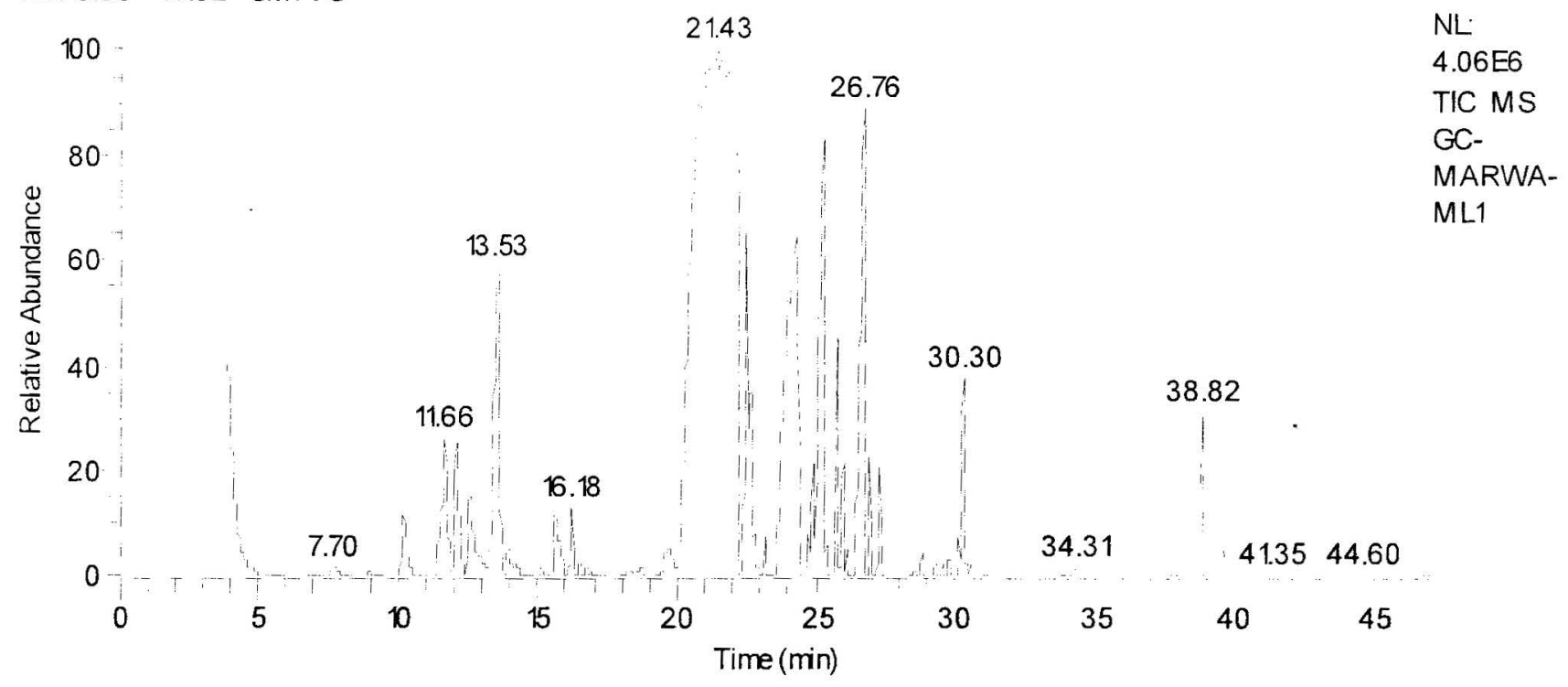

Fig. (1): Gas liquid chromatogram of wild mint oil, Mentha longifolia.

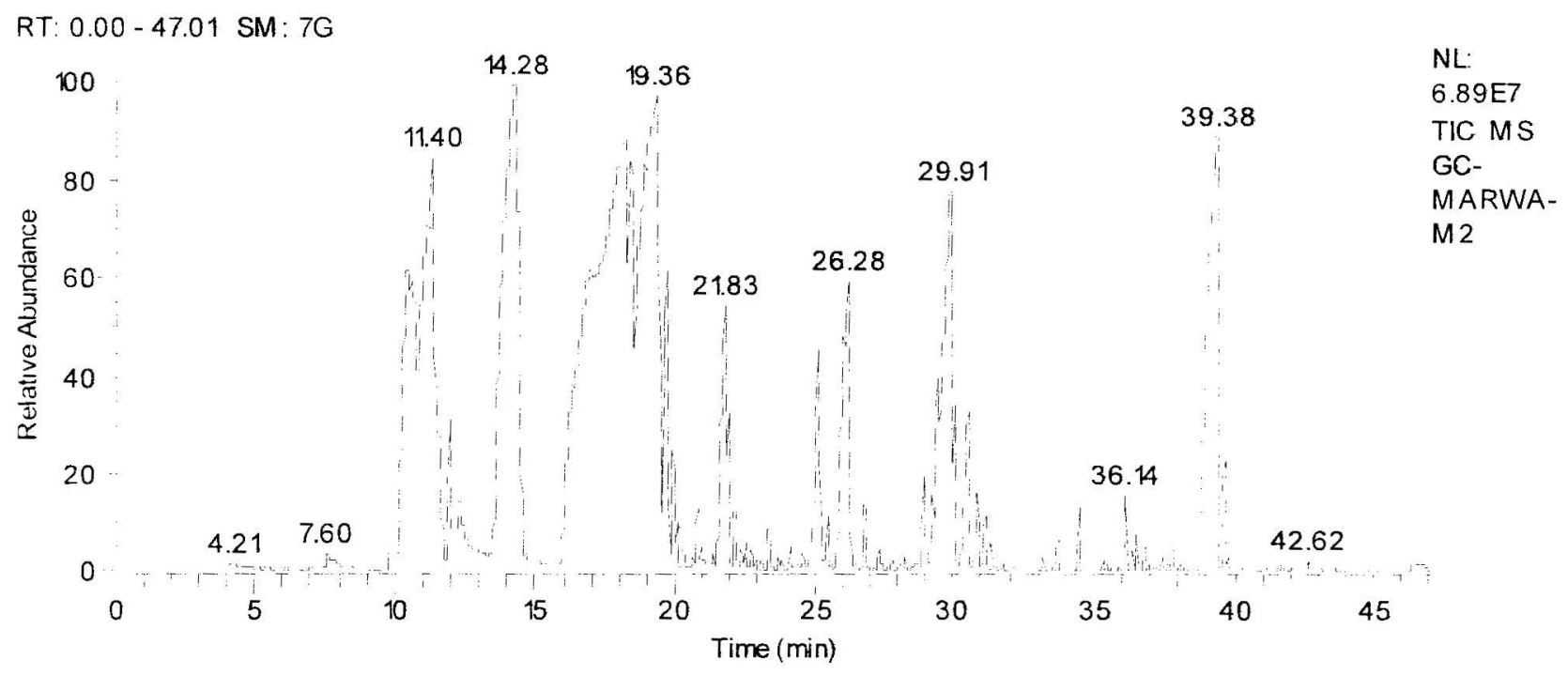

Fig. (2): Gas liquid chromatogram of sage oil, Salvia officinalis.

RT: $0.00-47.01$ SM: $7 \mathrm{G}$

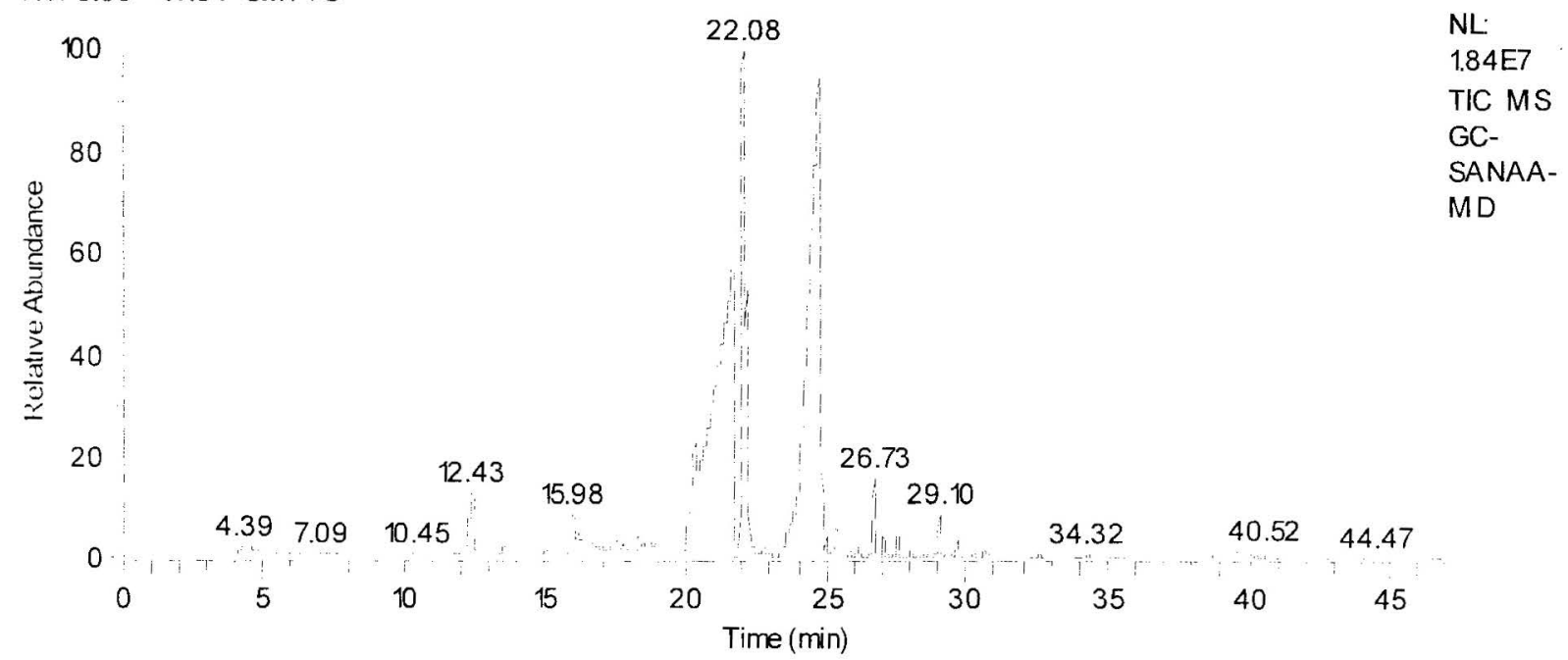

Fig. (3): Gas liquid chromatogram of dragon head oil, Dracocephalum moldavicae. 
Table (1): GC /MS analysis of the essential oil of wild mint, Mentha longifolia

\begin{tabular}{|c|c|c|c|c|}
\hline I. $\mathrm{C}$ & No. & Compound & $\begin{array}{c}\mathrm{R}_{\mathrm{t}} \\
(\mathrm{min} .)\end{array}$ & $\begin{array}{c}\text { Area } \\
(\%)\end{array}$ \\
\hline$*$ & 1 & $\alpha$-Pinene & 10.18 & 0.86 \\
\hline$*$ & 2 & Sabinene & 11.66 & 1.98 \\
\hline * & 3 & Myrcene & 12.09 & 1.38 \\
\hline * & 4 & 1,8-Cineole & 13.53 & 4.28 \\
\hline$*$ & 5 & Ocimene & 16.51 & 0.08 \\
\hline$*$ & 6 & Thujyl alcohol & 18.71 & 0.08 \\
\hline$*$ & 7 & Menthene isomer & 19.63 & 0.43 \\
\hline * & 8 & Cis-Piperitone oxide & 21.43 & 34.42 \\
\hline$*$ & 9 & Trans-Piperitone oxide & 21.58 & 19.31 \\
\hline$*$ & 10 & Elemene & 22.49 & 3.60 \\
\hline * & 11 & trans-Caryophyllene & 25.27 & 6.61 \\
\hline * & 12 & Farnesene & 25.78 & 1.38 \\
\hline$*$ & 13 & Humulene & 25.97 & 0.71 \\
\hline * & 14 & Cubebene & 26.74 & 6.24 \\
\hline$*$ & 15 & bicyclogermacrene & 26.93 & 0.40 \\
\hline * & 16 & Cadinene & 27.28 & 0.62 \\
\hline$*$ & 17 & Caryophyllene oxide & 28.82 & 0.10 \\
\hline * & 18 & Cadinol & 30.29 & 1.71 \\
\hline & & Total area of terpens & & 84.19 \\
\hline$*$ & 19 & 2-Hexenal & 7.71 & 0.14 \\
\hline$*$ & 20 & 3-Octanol & 12.56 & 1.04 \\
\hline$*$ & 21 & Isopentyl pentanoate & 15.59 & 0.93 \\
\hline$*$ & 22 & 3-octanyl acetate & 16.18 & 0.44 \\
\hline \multicolumn{4}{|c|}{ Total area of hydrocarbons } & 2.55 \\
\hline
\end{tabular}

Table (2): GC/MS analysis of the essential oil of sage, Salvia officinalis

\begin{tabular}{ccccc}
\hline I. C & No. & Compound & $\begin{array}{c}\mathrm{R}_{\mathrm{t}} \\
(\mathrm{min})\end{array}$ & $\begin{array}{c}\text { Area } \\
(\%)\end{array}$ \\
\hline$*$ & 1 & $\alpha$ - Pinene & 10.44 & 5.11 \\
$*$ & 2 & Camphene & 11.38 & 8.04 \\
$*$ & 3 & $\beta$-pinene & 11.98 & 1.08 \\
$*$ & 4 & 1,8 -Cincole & 14.25 & 18.64 \\
$*$ & 5 & trans-Caryophyllene & 16.31 & 1.95 \\
$*$ & 6 & Thujone & 16.62 & 0.99 \\
$*$ & 7 & Camphor & 19.37 & 13.26 \\
$*$ & 8 & Borneol & 19.73 & 2.98 \\
$*$ & 9 & Endobornyl acetate & 21.82 & 4.31 \\
$*$ & 10 & Trans-Caryophyllene & 25.17 & 2.71 \\
$*$ & 11 & Aromadendrene & 25.51 & 0.32 \\
$*$ & 12 & $\alpha$ - Ilumulene & 26.26 & 5.51 \\
$*$ & 13 & Ledene & 26.81 & 0.38 \\
$*$ & 14 & $(-)$-Caryophyllene oxide & 28.99 & 0.64 \\
$*$ & 15 & Veridiflorol & 29.89 & 8.59 \\
$*$ & 16 & Aristolen epoxide & 30.86 & 2.51 \\
$*$ & 17 & 13-Epimanool & 39.37 & 11.33 \\
\hline \multicolumn{4}{c}{ Tatal area of terpens $(\%)$} \\
\hline
\end{tabular}

Table (3): GCMS analysis of the essential oil of dragon head, Dracocephlum moldavicae

\begin{tabular}{|c|c|c|c|c|}
\hline I.C & No. & Compound & $\begin{array}{c}\mathrm{R}_{\mathrm{t}} \\
(\mathrm{min} \\
)\end{array}$ & $\begin{array}{l}\text { Area } \\
(\%)\end{array}$ \\
\hline * & 1 & limonene & 13.56 & 0.23 \\
\hline * & 2 & Delta-3-carene & 14.16 & 0.15 \\
\hline$*$ & 3 & Trans- Linalool oxide & 14.99 & 0.13 \\
\hline$*$ & 4 & D- Linalool & 15.97 & 1.46 \\
\hline$*$ & 5 & Trans-2-Pinanol & 16.16 & 1.02 \\
\hline * & 6 & L- linalool & 16.50 & 0.52 \\
\hline$*$ & 7 & Nerol oxide & 17.48 & 0.25 \\
\hline * & 8 & Limonene oxide & 17.78 & 0.24 \\
\hline * & 9 & Verbenol & 18.32 & 0.54 \\
\hline * & 10 & citrial & 20.32 & 2.41 \\
\hline * & 11 & trans-Geraniol & 21.63 & 24.07 \\
\hline$*$ & 12 & Nerol & 22.07 & 28.16 \\
\hline$*$ & 13 & Neryl acetate & 23.86 & 0.21 \\
\hline * & 14 & $\alpha$-humulene & 26.11 & 0.24 \\
\hline$*$ & 15 & Geranyl acetate & 4.79 & 29.99 \\
\hline$*$ & 16 & Cubebene & 26.72 & 1.61 \\
\hline$*$ & 17 & Farnesene & 27.06 & 0.38 \\
\hline * & 18 & Cadinene & 27.57 & 0.33 \\
\hline * & 19 & Caryophyllene oxide & 29.09 & 1.18 \\
\hline * & 20 & $\alpha-$ Cadinol & 30.32 & 0.11 \\
\hline \multirow[t]{2}{*}{ * } & 21 & Lavandulyl acetate & 32.59 & 0.09 \\
\hline & & Total area of terpens & & 93.32 \\
\hline * & 22 & 6-Methyl-5-hepten-2-one & 12.41 & 2.45 \\
\hline * & 23 & $\begin{array}{c}\text { 2,6-octadienoic acid ,3,7-dimethyl- } \\
\text {,methyl ester }\end{array}$ & 22.81 & 0.26 \\
\hline * & 24 & $\begin{array}{c}9,12.15 \text {-octadecatrienoicacid ,2.3- } \\
\text { bis (acetyloxy) propyl ester }\end{array}$ & 24.99 & 0.11 \\
\hline * & 25 & Cis - caryophyllene & 25.35 & 0.89 \\
\hline * & 26 & $\begin{array}{l}\text { 5,9,-undecadien-2-one, } 6 \\
\text { 10-dimethyl-.(E)-(GAS) }\end{array}$ & 25.86 & 0.12 \\
\hline * & 27 & $\begin{array}{l}\text { 3- Butyl-4-methyl-2- } \\
\text { methylthiothiophene }\end{array}$ & 28.05 & 0.14 \\
\hline * & 28 & $\begin{array}{c}\text { 2- pentadecanone, } 6,10,14- \\
\text { trimethyl- }\end{array}$ & 34.32 & 0.11 \\
\hline * & 29 & $\begin{array}{l}\text { Neopentyl difluoro(3-phenyl- } \\
\text { phenyl) methane sulfonate }\end{array}$ & 39.59 & 0.25 \\
\hline * & 30 & 7-hydroxy- 6-keto-drimanol & 40.12 & 0.12 \\
\hline * & 31 & $\begin{array}{l}\text { 2.6- octadiene,3,7-dimethyl-1- } \\
\text { (2-propenyloxy)- }\end{array}$ & 40.52 & 0.13 \\
\hline & & Total area of hydrocarbons & & 4.58 \\
\hline
\end{tabular}

Table (4): Toxicity of Mentha longifolia, Salvia officinalis and Dracocephalum moldavicae plant essential oils against adult females and eggs of Tetranychus urticae.

\begin{tabular}{lcccccc}
\hline \multirow{2}{*}{ Toxicity parameter } & \multicolumn{2}{c}{ D. moldavicae oil } & \multicolumn{2}{c}{ S. officinalis oil } & \multicolumn{2}{c}{ M. longifolia oil } \\
\cline { 2 - 6 } & adults & eggs & adults & eggs & adults & eggs \\
\hline LC $5 \%$ & 1.57 & 0.58 & 2.24 & 3.33 & 2.85 & 3.52 \\
Lower Limit & 1.44 & 0.17 & 1.90 & 2.81 & 2.22 & 2.79 \\
Upper Limit & 1.73 & 0.82 & 2.79 & 4.32 & 4.85 & 5.01 \\
Folds & 1.81 & 6.07 & 1.27 & 1.06 & 1 & 1 \\
Toxicity index & 100 & 100 & 70 & 17 & 55 & 16 \\
Slope & 3.93 & 2.29 & 1.79 & 3.01 & 2.27 & 2.07 \\
I. $C_{90} \%$ & 3.32 & 2.11 & 11.60 & 8.88 & 10.43 & 14.62 \\
\hline
\end{tabular}


Toxicity effects of Mentha longifolia, Salvia officinalis and Dracocephalum moldavicae on $T$. urticae eggs and adult females

Table (4) shows that all essential oils tested had toxic effects against females and eggs of $T$. urticae. D. moldavicae oil was the most potent oil tested against females $\left(\mathrm{LC}_{50}=1.57 \& \mathrm{LC}_{90}=3.32 \%\right)$ and eggs $\left(\mathrm{LC}_{50}=0.58 \& \mathrm{LC}_{90}=2.11\right)$ of $T$. urticae, while $M$. longifolia oil was the least toxic oil tested on females $\left(\mathrm{LC}_{50}=2.85 \& \mathrm{LC}_{90}=10.43 \%\right)$ and eggs $\left(\mathrm{LC}_{50}=3.52 \& \mathrm{LC}_{90}=14.62\right)$. Eggs of $T$. urticae treated with $D$. moldavicae oil were more susceptible than females. Results also showed that $S$. officinalis and $M$. longifolia oils were more effective to females than eggs. When $S$. officinalis oil was used as a fumigant for T. urticae, it had more toxic effect on females than on eggs (Choi et al., 2004).

Several authors demonstrated the efficiency of various essential oils derived from plants belonging to the family Lamiaceae, (e. g.: Satureja hortensis L., Thymus vulgaris L., Ocimum basilicum, Micromeria fruticosa L., Nepeta racemosa L., Origanum vulgara $\mathrm{L}$. and Marjorana hortensis L.) against T. urticae (Aslan et al., 2004; Calmasur et al., 2006 and Afify et al., 2009). It is worth to mention that Baker (2003) proved that females of $T$. urticae were more sensitive to Petroselinum sativum L., Coriandrum sativum oils (family: Apiaceae) than eggs.

The essential oils composition including, limonene, 1,8- cineole, linalool, anethole, camphor, geraniol $\alpha$ - terpinene, found in the this study, were reported to be responsible for the toxic effect on eggs and females of $T$. urticae and
T. cinnabarinus Boisd by Erler \& Tunc. (2005). El-Zemity et al., (2009) and Badawy e't al.. (2010).

\section{Repellency test for $T$. urticae females:}

Table (5) shows that the tested plant essential oils strongly deterred $T$. urticae females $(99.85 .99 .51$ and $97.19 \%$, respectively) at $L_{50}$ of each essential oil. The deterrent effect increased at all concentrations in dragon head oil. while the percentage of repellency decreased at lower concentrations of sage oil.

Essential oils of Mentha viridis L.. Mentha piperita L., Rosmarinus officinalis L.. .M. hortensis. $O$. basilicum, Lavandula officinalis $L$. and . Iinthu spicata L. deterred females of $T$. urticae from settlement and feeding on treated parts. Amer et al.. (2001); Momen et al., (2001); Refaat et al., (2002) and Omar et al., (2009)

\section{Effect of $\mathrm{LC}_{50}$ of essential oils on some biological aspects of $T$. urticae females:}

Data in Table (6) indicated that all treatments at level of $\mathrm{LC}_{50}$ were highly significantly shortened the oviposition period, female longevity and reduced the number of eggs laid per female; while prolonged pre-oviposition period of eggs compared with control.

Dracocephalum moldavicae oil had a highly significant remarkable shortness on oviposition period and female longevity, (ANOVA; $\mathrm{F}=269.46$ $\left.\& 190.54, \mathrm{df}_{1,2} 3,76, P=0.000\right)$, respectively.

Pre-oviposition period was significantly prolonged by $M$. longifolia oil, $(\mathrm{ANOVA} ; \mathrm{F}=55.94$,

Table (5): Relative distribution and repellency of Tetranychus urticae on treated leaf discs with Mentha longifolia, Salvia officinalis and Dracocephalum moldavicae essential oils

\begin{tabular}{|c|c|c|c|c|c|c|c|c|}
\hline \multirow{2}{*}{$\begin{array}{c}\text { Concentration } \\
(\%)\end{array}$} & \multicolumn{5}{|c|}{$\%$ Distribution of mites on treated leaf discs after } & \multicolumn{2}{|c|}{ Avrg. no. of eggs/female after $48 \mathrm{~h}$} & \multirow{2}{*}{$\begin{array}{c}\text { Repellency } \\
\%\end{array}$} \\
\hline & $2 \mathrm{~h}$ & $4 \mathrm{~h}$ & $6 \mathrm{~h}$ & $24 \mathrm{~h}$ & $48 \mathrm{~h}$ & $\mathrm{~T}$ & $\mathrm{C}$ & \\
\hline \multicolumn{9}{|l|}{ M. longifolia oil } \\
\hline 2.85 & 2 & 2 & 1 & 1 & 1 & 0.05 & 10.20 & 99.51 \\
\hline 1.42 & 2 & 2 & 2 & 2 & 1 & 0.06 & 11.61 & 99.48 \\
\hline 0.71 & 2 & 3 & 3 & 2 & 2 & 0.10 & 12.72 & 99.21 \\
\hline 0.35 & 15 & 11 & 6 & 13 & 22 & 1.32 & 12.10 & 89.67 \\
\hline \multicolumn{9}{|l|}{ S. officinalis oil } \\
\hline 2.24 & 1 & 2 & 3 & 2 & 7 & 0.3 & 10.68 & 97.19 \\
\hline 1.12 & 2 & 2 & 2 & 5 & 19 & 0.61 & 10.76 & 94.33 \\
\hline 0.56 & 2 & 4 & 3 & 14 & 37 & 3.33 & 7.71 & 55.81 \\
\hline 0.28 & 11 & 12 & 13 & 28 & 51 & 5.25 & 6.03 & 12.94 \\
\hline \multicolumn{9}{|l|}{ D. moldavicae } \\
\hline oil 1.57 & 1 & 1 & 0 & 0 & 0 & 0.01 & 6.56 & 99.85 \\
\hline 0.78 & 1 & 0 & 1 & 0 & 1 & 0.03 & 6.74 & 99.55 \\
\hline 0.39 & 4 & 0 & 1 & 0 & 6 & 0.11 & 7.44 & 98.52 \\
\hline 0.19 & 5 & 0 & 1 & 6 & 9 & 0.14 & 8.53 & 98.36 \\
\hline
\end{tabular}


Table (6): Effect of Mentha longifolia, Salvia officinalis and Dracocephalum moldavicae essential oils on some biological aspects of Tetranychus urticae

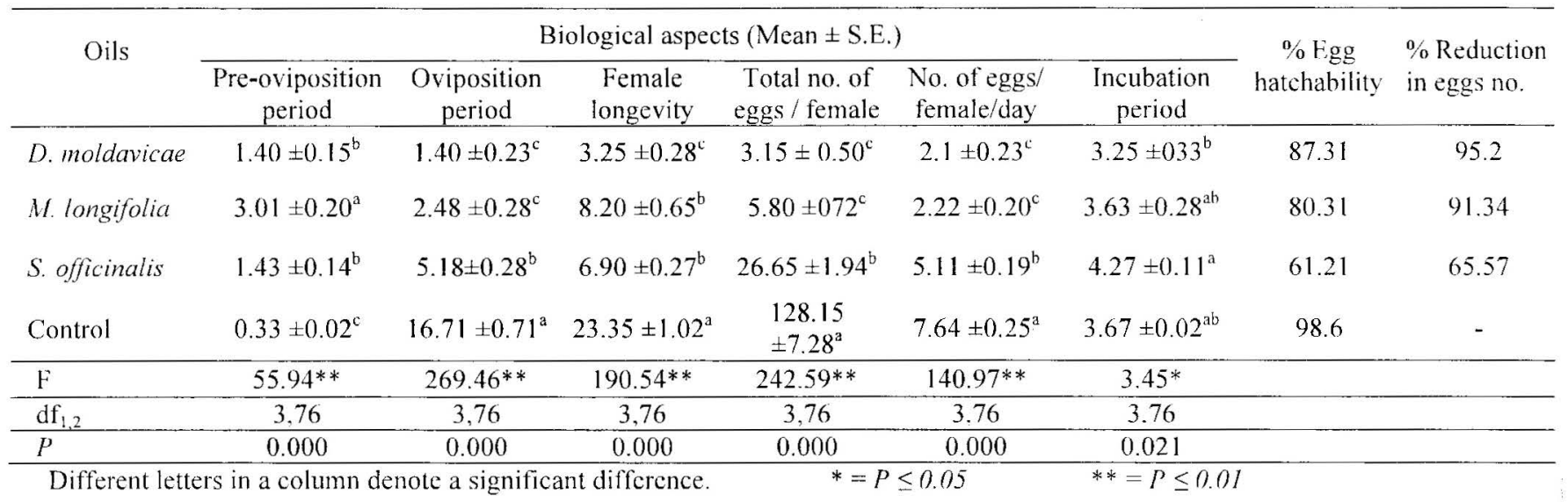

$\left.\mathrm{df}_{1,2} 3,76, P=0.000\right)$. The incubation period of eggs resulted from females treated with $S$. officinalis oil significantly prolonged, $\left(\right.$ ANOVA; $F=3.45, \mathrm{df}_{\mathrm{I}, 2}$ $3,76, P=0.021)$.

A highly significant reduction in the total number of eggs laid per female for all essential oils was recorded. Interestingly, oils of $D$. moldavicae and $M$. longifolia showed the highest reduction in the fecundity (95.2 \& 91.34\%) and the highest percentage of egg hatchability $(87.31 \& 80.31 \%)$, respectively. The lowest reduction in the fecundity (65.57\%), and the lowest eggs hatchability (61.21\%) was reported in S. officinalis oil.

These results are in agreement with that of, Ibrahim and Amer (1992) who demonstrated that essential oil from Callistemon lanceolatus Dc. (family: Myrtaceae ) had a strong effect on some biological aspects of $T$. urticae females since the female longevity and oviposition period were shortened while, the pre-oviposition and incubation periods of deposited eggs were prolonged. Similarly, oils from $T$. vulgaris, $M$. viridis, $M$. piperita, $R$. officinalis, $M$. hortensis, $L$. officinalis, and $M$. spicata caused a reduction in the total number of eggs laid by females $T$. urticae. (EL-Gengaihi et al., 1996; Amer et al., 2001; Momen et al., 2001; Refaat et al., 2002; and Omar et al., 2009).

The present results clearly confirm that essential oils from aromatic plants belonging to the family Lamiacea revealed acaricidal activity against eggs and females of T. uricae. Essential oils from dragon head plant showed the highest acaricidal activity against $T$. urticae and this result could be due to the higher concentrations of terpens compound, transgeraniol $(24.07 \%)$. nerol $(28.16 \%)$ and geranyl acetate $(29.99 \%)$. Each compound has a chemical structure allows the compound to penetrate and go directly to the active site to make its action. So, the differences of the biological activity of oils depend on the differences of the chemical structure of the compounds (Carveior et al., 1982).

\section{REFERENCES}

Adams, R. 2001. Essential oil components by quadruple GC/MS. Allured Publishing Corp, Carol Stream, IL.

Afify, A. M. R.; Ali, F. S.; Mohamed, M. A. and Turky, A. F. 2009. Acaricidal activity of essential oils of Chamomile, Marjoram and Eucalyptus against the Two-spotted spider mite, Tetranychus urticae Koch: biology and enzymes. Acarines, 3: 9-15.

Amer, S. A. A.; Refaat, A. M. and Momen, F. M. 2001. Repellent and oviposition-deterring activity of Rosemary and Sweet Marjoram on the spider mites Tetranychus urticae and Eutetranychus orientalis (Acari: Tetranychidae). Acta Phytopathol.et Entomol. Hung., 36 (1-2): $155-$ 164.

Aslan, I.; Ozbek, H.: Calmasur, O. and Sahin, F. 2004. Toxicity of essential oil vapors to two greenhouse pests. Tetranychus urticac Koch and Bemisia tabasi Genn. Ind. Crop. Prod., 19 (2): 167-173.

Badawy, M. E. I.; El-Arami, S. A. A. and Abdelgaleil. S. A. M. 2010. Acaricidal and quantitative structure activity relationship of monoterpenes against the two-spotted spider mite, Tetranychus urticae. Exp. Appl. Acarol. 52(3): 261-274

Bakkali, F.; Averbeck, S.; Averbeck, D. and Idaomar, M. 2008. Biological effects of essential oils - A review. Food and Chemical Toxicology. 46: 446-475.

Baker, E.M. 2003. Phytochemical and toxicological studies on essential oils of aromatic plants against Tetranychus urticae koch. Ph. D. Thesis, Fac. Agric., Cairo Univ., PP. 150.

Calmasur. O.: Aslan. I. and Salin. F. 2006. 
Insecticidal and acaricidal effect of three Lamiaceae plant essential oils against Tetranychus urticae Koch. and Bemisia tabaci Genn. Ind. Crop. Prod., 23 (2): 140-146.

Carveior, A. A.; Androde, C. H. S.; Matos, F. J. A.; Alencar, J, W. and Machado, M.I.L.1982. J. of Natural Products., 46: 4.

Choi, W. I.; Lee, S.G.; Park, H. M. and Ahn, Y. J. 2004. Toxicity of plant essential oils to Tetranychus urticae (Acari: Tetranychidae) and Phytoseiulus persimilis (Acari: Phytoseiidae). J. Econ. Entomol., 97 (2): 553-558.

Cohen, E. 2006. Pesticide-mediated homeostatic modulation in arthropods. Pesticide Biochemistry and Physiology 85: 21-27

El-Gengaihi, S. E.; Amer, S. A. A. and Mohamed, S. M. 1996. Biological activity of thyme oil and thymol against Tetranychus urticae Koch. J. Pest. Sci., 69: 157-159.

El-Zemity, S. R.; Rezk, H. A. and Zaitoon, A. A. 2009. Acaricidal potential of some essential oils and their monoterpenoides against the twospotted spider mite, Tetranychus urticae (Koch). Arch. Phytopath. \& Plant Prot., 42(4): 334-339.

E:ler, F. and Tunk, I. 2005. Monoterpenoids as fumigants against greenhouse pests: toxic, development and reproduction-inhibiting effects. J. Plant Dis. and Protection, 112 (2): 181-192.

Finney, M. 1971. Probit analysis. Cambridge Univ. Press. 3rd ed., London.

Gorman, K.; Hewitt, F.; Denholm, I. and Devine, G. J. 2002. New developments in insecticide resistance in the glasshouse whitefly (Trialeurodes vaporariorum) and the two-spotted spider mite (Tetranychus urticae) in the UK. Pest Manag. Sci., 58 (2): 123-130.

Hardman, J. M.; Franklin, J. L.; Jensen, K. I. N.; and Moreau, D. L. 2006. Effects of pesticides on mite predators (Acari: Phytoseiidae) and colonization of Apple trees by Tetranychus uricae. Phytoparasitica 34 (5): 449-462.

Helle, W.and Sabelis, M.W. 1985. Spider mites: their biology, natural enemies and control, vol 1B. Elsevier, Amsterdam.

tbrahim, M. E. and Amer, S.A.A. 1992. Chemical and acaricidal studies on the essential oil of Callistemon lanceolatus Dc. Plant grown in Egypt . J. Appl. Sci. 7: 445- 456.

ibrahin, M. A., Kumainen, P., intatuni, A.; Tiilikkala, K. and Holopainen, J. K. 2001. Insectcidal, repellent, antimicrobial activity and phytotoxicity of essential oils: with special reference to limonene and its suitability for control of insect pests. Agr. Food Sci.. 10:243259.

Kim, Y. J.; Lee, S.W.; Cho, J. R.; Park, H. M. and Ahn, Y. J. 2007. Multiple resistance and biochemical mechanisms of dicofol resistance in Tetranychus urticae (Acari: Tetranychidae). J. Asia-Pacific

Entomol.. $10(2): 165-170$

Klocke, J.A. 1989. Plant compounds as source and models of insectcontrol agents. In: Hostettmann, K. (Ed.), Economic and Medicinal Plant Research. Academic Prcss, London, pp. 103-144. Lwande, W.; Hassanali, P. W.;" Njoroge, P. W.; Bentely, M. D.; Delle Monache, F. and Jondiko, J. I. 1985. A new 6, a-hydroxy pterocarpon with insect antifeedant and antifungal properties from the roots of Tephrosia hildebrantii Vatke. Insect. Sci. Applic., 6: 537- 547.

Mansour, F., Ravid, U. and Putievsky, E. 1986. Studies on the effects of essential oils isolated from 14 species of Labiatae on the carmine spider mite, Tetranychus cimnabarinus. Phytoparasitica, 14:137-142.

Momen, F. M.; Amer, S. A. A. and Refaat, A. M. 2001. Influence of mint and peppermint on Tetranychus urticue and some predacious mites of the family Phytoseiidae (Acari: Tetranychidae: Phytoseiidae). Acta Phytopathol. et Entomol. Hungarica, $36(1-2)$ : 143-153.

Omar, N. A.; El-Sayed, Z. I. A. and Romeh, A. A. 2009. Chemical constituents and biological activity of the essential oil of Mentha spicata L. grown in Zagazig region, Egypt. J. Agric. Bio. Sci., 5 (6): 1089-109?.

Refaat, A. M.; Momen, F. M. and Amer, S. A. A. 2002. Acaricidal activity of Sweet Basii and

French iavender essential oils against two species of mites in the family Tetranychidae (Acari: Tetranychidae). Acta Phytopathoiet Entomol. Hungarica, 37 (1-3): 287-298.

Regnault-Roger, C. 1997. The potential of botanical essential oils for insect pest control. Int. Pest Manag. Reviews, 2: 25-34

Tunc, I. and Sahinkaya, S. 1998. Sensitivity of two greenhouse pests to vapours of essential oils. Entomol. Exp. Appl., 86:183-187.

Van-Leeuwen, T.; Vontas, I.: Tsagkarakou, A.; Dermauw, W. and Tirry. L. 2016 Acaricide resistance mechanisms in the two-spotted spider mite Tetranychus urticac and other important Acari: A review. Insect Bio. and Molec. Biol., 30: $1-10$ 